\title{
Front Matter: Volume 7876
}

, "Front Matter: Volume 7876," Proc. SPIE 7876, Digital Photography VII, 787601 (24 January 2011); doi: 10.1117/12.883178

EPIE Event: IS\&T/SPIE Electronic Imaging, 2011, San Francisco Airport, California, SPIE. United States 


\title{
PROCEEDINGS \\ IS\&T / SPIE \\ Electronic \\ Imaging \\ SCIENCE AND TECHNOLOGY
}

\section{Digital Photography VII}

\author{
Francisco H. Imai \\ Feng Xiao \\ Jeffrey M. DiCarlo \\ Nitin Sampat \\ Sebastiano Battiato \\ Editors
}

24-25 January 2011

San Francisco, California, United States

Sponsored and Published by

IS\&T-The Society for Imaging Science and Technology

SPIE

Cosponsored by

Fairchild Imaging (United States)

Canon U.S.A. Inc. (United States) 
The papers included in this volume were part of the technical conference cited on the cover and title page. Papers were selected and subject to review by the editors and conference program committee. Some conference presentations may not be available for publication. The papers published in these proceedings reflect the work and thoughts of the authors and are published herein as submitted. The publisher is not responsible for the validity of the information or for any outcomes resulting from reliance thereon.

Please use the following format to cite material from this book:

Author(s), "Title of Paper," in Digital Photography VII, edited by Francisco H. Imai, Feng Xiao,

Jeffrey M. DiCarlo, Nitin Sampat, Sebastiano Battiato, Proceedings of SPIE Vol. 7876 (SPIE, Bellingham, WA, 2011) Article CID Number.

ISSN 0277-786X

ISBN 9780819484130

Published by

SPIE

P.O. Box 10, Bellingham, Washington $98227-0010$ USA

Telephone +1 3606763290 (Pacific Time) · Fax +1 3606471445

SPIE.org

Copyright (@ 2011, Society of Photo-Optical Instrumentation Engineers

Copying of material in this book for internal or personal use, or for the internal or personal use of specific clients, beyond the fair use provisions granted by the U.S. Copyright Law is authorized by SPIE subject to payment of copying fees. The Transactional Reporting Service base fee for this volume is $\$ 18.00$ per article (or portion thereof), which should be paid directly to the Copyright Clearance Center (CCC), 222 Rosewood Drive, Danvers, MA 01923. Payment may also be made electronically through CCC Online at copyright.com. Other copying for republication, resale, advertising or promotion, or any form of systematic or multiple reproduction of any material in this book is prohibited except with permission in writing from the publisher. The CCC fee code is 0277-786X/11/\$18.00.

Printed in the United States of America.

Publication of record for individual papers is online in the SPIE Digital Library.

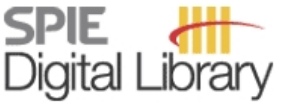

SPIEDigitalLibrary.org

Paper Numbering: Proceedings of SPIE follow an e-First publication model, with papers published first online and then in print and on CD-ROM. Papers are published as they are submitted and meet publication criteria. A unique, consistent, permanent citation identifier (CID) number is assigned to each article at the time of the first publication. Utilization of CIDs allows articles to be fully citable as soon they are published online, and connects the same identifier to all online, print, and electronic versions of the publication. SPIE uses a six-digit CID article numbering system in which:

- The first four digits correspond to the SPIE volume number.

- The last two digits indicate publication order within the volume using a Base 36 numbering system employing both numerals and letters. These two-number sets start with 00, 01, 02, 03, 04 , 05, 06, 07, 08, 09, OA, OB ... 0Z, followed by 10-1Z, 20-2Z, etc.

The CID number appears on each page of the manuscript. The complete citation is used on the first page, and an abbreviated version on subsequent pages. Numbers in the index correspond to the last two digits of the six-digit CID number. 


\section{Contents}

vii Conference Committee
ix Introduction

SESSION 1 INVITED PAPER

787602 High dynamic range image sensor architectures (Invited Paper) [7876-01]

B. Fowler, Fairchild Imaging (United States)

\section{SESSION 2 COMPUTATIONAL PHOTOGRAPHY}

787603 Bayer and panchromatic color filter array demosaicing by sparse recovery [7876-02] M. Aghagolzadeh, A. Abdolhosseini Moghadam, Michigan State Univ. (United States); M. Kumar, Eastman Kodak Co. (United States); H. Radha, Michigan State Univ. (United States)

787604 Improved motion invariant imaging with time varying shutter functions [7876-03] S. Webster, A. Dorrell, Canon Information Systems Research Australia Pty. Ltd. (Australia)

787605 Optimal image acquisition by auto-defocusing [7876-04]

T. Ma, S. J. Reeves, Auburn Univ. (United States)

787606 Mobile phone imaging module with extended depth of focus based on axial irradiance equalization phase coding [7876-05]

H.-Y. Sung, National Tsing Hua Univ. (Taiwan) and Industrial Technology Research Institute (Taiwan); P.-C. Chen, C.-C. Chang, C.-W. Chang, Industrial Technology Research Institute (Taiwan); S. S. Yang, National Tsing Hua Univ. (Taiwan); H. Chang, Industrial Technology Research Institute (Taiwan)

787607 Performance of extended depth of field systems and theoretical diffraction limit [7876-06] N. Bachelard, F. Guichard, F. Cao, I. Tarchouna, DxO Labs. (France)

\section{SESSION 3 SPECTRAL IMAGING}

787608 Implementation of a multispectral color imaging device without color filter array [7876-07] G. Langfelder, A. F. Longoni, F. Zaraga, Politecnico di Milano (Italy)

787609 One-shot multispectral color imaging with a stereo camera [7876-08] R. Shrestha, J. Y. Hardeberg, Gjøvik Univ. College (Norway); A. Mansouri, Univ. de Bourgogne (France)

7876 OA Multispectral image invariant to illumination colour, strength, and shading [7876-09] M. S. Drew, A. Yazdani Salekdeh, Simon Fraser Univ. (Canada) 
$7876 \mathrm{OB} \quad$ Methods for spectral characterization of multispectral cameras [7876-10]

J. Klein, J. Bravers, T. Aach, RWTH Aachen Univ. (Germany)

\section{SESSION 4 IMAGE PROCESSING}

7876 OC Evaluation of a hyperspectral image database for demosaicking purposes [7876-11]

M.-C. Larabi, XLim Lab., CNRS, Univ. de Poitiers (France); S. Süsstrunk, Ecole Polytechnique Fédérale de Lausanne (Switzerland)

7876 OD Automatic annotation of outdoor photographs [7876-12]

C. Cusano, R. Schettini, Univ. degli Studi di Milano-Bicocca (Italy)

7876 OE Fast orientation driven multi-structure morphological inpainting [7876-13]

D. J. Florinabel, S. E. Juliet, V. Sadasivam, Manonmanium Sundaranar Univ. (India)

\section{SESSION 5 SENSORS AND OPTICS}

7876 OF How many pixels does it take to make a good 4"×6" print? Pixel count wars revisited [7876-14]

M. A. Kriss, MAK Consultants (United States)

$78760 \mathrm{~A}$ A prototype high-speed CMOS image sensor with 10,000,000 fps burst-frame rate and 10,000 fps continuous-frame rate [7876-15]

Y. Tochigi, K. Hanzawa, Y. Kato, N. Akahane, R. Kuroda, S. Sugawa, Tohoku Univ. (Japan)

$7876 \mathrm{OH} \quad$ Two-dimensional measurement of the lens optical transfer function from a digital image [7876-16]

D. P. Morgan-Mar, M. R. Arnison, C. A. Deller, P. A. Fletcher, K. G. Larkin, Canon Information Systems Research Australia Pty. Ltd. (Australia)

\section{SESSION 6 IMAGE ENHANCEMENT}

7876 Ol Efficient defect pixel cluster detection and correction for Bayer CFA image sequences [7876-17]

T. Tajbakhsh, Dream Chip Technologies GmbH (Germany)

7876 0J Image scaling with aliasing cancellation [7876-18]

A. Tõnisson, A. Dorrell, N. Mehrseresht, R. Zillman, Canon Information Systems Research Australia Pty. Ltd. (Australia)

7876 OK Random-temporal block selection for video stabilization [7876-19]

S. Battiato, Univ. degli Studi di Catania (Italy); A. R. Bruna, STMicroelectronics (Italy);

G. Puglisi, Univ. degli Studi di Catania (Italy) 
7876 OL Comparison of objective metrics for image sensor crosstalk characterization [7876-20] F. Li, Aptina Imaging, Inc. (United States); H. Eliasson, Sony Ericsson Mobile Communications AB (Sweden); A. Dokoutchaev, Aptina Imaging, Inc. (United States)

$78760 \mathrm{M}$ An image quality evaluation tool simulating image sensors including quantum efficiency off-axis effect [7876-21]

C. Mornet, STMicroelectronics (France) and Institut de Microélectronique Électromagnétisme et Photonique (France); J. Vaillant, T. Decroux, N. Virollet, D. Herault, STMicroelectronics (France); I. Schanen, Institut de Microélectronique Électromagnétisme et Photonique (France)

7876 ON Image quality assessment based on edge [7876-22]

X. Mou, M. Zhang, W. Xue, Xi'an Jiaotong Univ. (China); L. Zhang, The Hong Kong Polytechnic Univ. (Hong Kong, China)

SESSION 8 HIGH DYNAMIC RANGE IMAGING: JOINT SESSION WITH CONFERENCE 7867

787600 Method for evaluating tone mapping operators for natural high dynamic range images [7876-23]

M. Kuhna, M. Nuutinen, P. Oittinen, Aalto Univ. School of Science and Technology (Finland)

7876 OP High dynamic range imaging of non-static scenes [7876-24]

I. Hossain, B. K. Gunturk, Louisiana State Univ. (United States)

\section{INTERACTIVE POSTER SESSION}

$78760 Q$ Toward a quantitative visual noise evaluation of sensors and image processing pipes [7876-25]

C. Mornet, STMicroelectronics (France) and Institut de Microélectronique Électromagnétisme et Photonique (France); D. Baxter, STMicroelectronics (United Kingdom); J. Vaillant, T. Decroux, D. Herault, STMicroelectronics (France); I. Schanen, STMicroelectronics (United Kingdom)

7876 OR Fidelity tolerance analysis for computational imaging system [7876-26]

C.-C. Chang, Y.-L. Chen, K.-V. Chen, H.-Y. Tsao, H.-Y. Sung, C.-W. Chang, P.-C Chen, H. Chang, Industrial Technology Research Institute (Taiwan)

7876 OS Noise-robust image deblurring by blending regular- and short-exposure images [7876-27] Y. Tsuda, H. Hatanaka, S. Fukumoto, M. Ueda, SANYO Electric Co., Ltd. (Japan); K. Chihara, Nara Institute of Science and Technology (Japan)

7876 OT Improving the sensitometric and OECF standards: recognizing the photosensitive exposure range [7876-28]

M. G. Prais, Consultant (United States)

7876 OU Image enhancement technique using color and edge features for mobile systems [7876-29] W.-H. Cho, T.-C. Kim, SAMSUNG Electronics Co., Ltd. (Korea, Republic of) 
7876 OV Rectangular pixels for efficient color image sampling [7876-30]

T. Singh, M. Singh, Image Algorithmics (United States)

7876 OW A robust color signal processing with wide dynamic range WRGB CMOS image sensor [7876-31]

S. Kawada, R. Kuroda, S. Sugawa, Tohoku Univ. (Japan)

7876 OX Adaptive contrast enhancement for underexposed images [7876-32]

S. Corchs, F. Gasparini, R. Schettini, Univ. of Milano-Bicocca (Italy)

$78760 Z$ Moving refractive optical low-pass filter for digital cameras [7876-34]

M. Schöberl, Friedrich-Alexander-Univ. Erlangen-Nürnberg (Germany); J. Ernst, FraunhoferInstitut für Integrierte Schaltungen (Germany); W. Schnurrer, Friedrich- Alexander-Univ. Erlangen-Nürnberg (Germany) and Fraunhofer-Institut für Integrierte Schaltungen (Germany); S. Fößel, Fraunhofer-Institut für Integrierte Schaltungen (Germany); A. Kaup, Friedrich-Alexander-Univ. Erlangen-Nürnberg (Germany)

787610 A JPEG-like algorithm for compression of single-sensor camera image [7876-35] O. Benahmed Daho, M.-C. Larabi, XLim Lab., CNRS, Univ. de Poitiers (France); J. Mukhopadhyay, Indian Institute of Technology, Kharagpur (India)

$787611 \quad$ Reduced reference image quality assessment based on statistics of edge [7876-36] M. Zhang, W. Xue, X. Mou, Xi'an Jiaotong Univ. (China)

787612 Evaluation of LED flash performance for camera phones [7876-37]

J. Pincenti, C. Sheldon, B.-H. Richards, G. John, Motorola, Inc. (United States)

787613 Characterization of pixel crosstalk and impact of Bayer patterning by quantum efficiency measurement [7876-39]

J. Vaillant, STMicroelectronics (France); C. Mornet, STMicroelectronics (France) and Institut de Microélectronique, Electromagnétisme et Photonique (France); T. Decroux, D. Hérault, STMicroelectronics (France); I. Schanen, Institut de Microélectronique, Electromagnétisme et Photonique (France)

Author Index 


\title{
Conference Committee
}

\author{
Symposium Chair
}

Sabine Süsstrunk, École Polytechnique Fédérale de Lausanne

(Switzerland)

Symposium Cochair

Majid Rabbani, Eastman Kodak Company (United States)

Conference Chairs

Francisco H. Imai, Canon U.S.A., Inc. (United States)

Feng Xiao, Fairchild Imaging (United States)

\section{Conference Cochairs}

Jeffrey M. DiCarlo, Intuitive Surgical (United States)

Nitin Sampat, Rochester Institute of Technology (United States)

Sebastiano Battiato, Università degli Studi di Catania (Italy)

Program Committee

Donald J. Baxter, STMicroelectronics (R\&D) Ltd. (United Kingdom)

Ajit S. Bopardikar, Samsung Electronics, India Software Operations Ltd. (India)

Peter B. Catrysse, Stanford University (United States)

Ted J. Cooper, Lens Vector, Inc. (United States)

Alexandru F. Drimbarean, Tessera (FotoNation) Ireland Ltd. (Ireland)

Joyce E. Farrell, Stanford University (United States)

Guotong Feng, Ricoh Innovations, Inc. (United States)

Boyd A. Fowler, Fairchild Imaging (United States)

Sergio R. Goma, Qualcomm Inc. (United States)

Mirko Guarnera, STMicroelectronics (Italy)

Frédéric Guichard, DxO Laboratoires (France)

Xiaoyun Jiang, Qualcomm Inc. (United States)

George John, Motorola, Inc. (United States)

Michael A. Kriss, Consultant (United States)

Jiangtao Kuang, OmniVision Technologies, Inc. (United States)

Feng Li, Aptina Imaging Corporation (United States)

J. Dylan Li, LifeSize Communications (United States)

Kevin J. Matherson, Hewlett-Packard Company (United States)

Jon S. McElvain, Digital Imaging Systems (United States)

Ricardo J. Motta, Consultant (United States) 
Seishi Ohmori, Nikon Corporation (Japan)

Manu Parmar, Qualcomm Inc. (United States)

Gloria G. Putnam, Eastman Kodak Company (United States)

John R. Reinert-Nash, Lifetouch, Inc. (United States)

M. Dirk Robinson, Skybox Imaging (United States)

Brian G. Rodricks, Fairchild Imaging (United States)

Todd Sachs, Aptina Imaging Corporation (United States)

Qun Sun, Aptina Imaging Corporation (United States)

Sabine E. Süsstrunk, Ecole Polytechnique Fédérale de Lausanne (Switzerland)

Touraj Tajbakhsh, Dream Chip Technologies (Germany)

Radka Tezaur, Nikon Precision Inc. (United States)

Michael Wang, Cisco Systems, Inc. (United States)

Dietmar Wüller, Image Engineering (Germany)

Weihua Xiong, OmniVision Technologies, Inc. (United States)

Alireza Yasan, Foveon Inc. (United States)

Lei Zhang, The Hong Kong Polytechnic University (Hong Kong, China)

Session Chairs

1 Invited Paper

Francisco H. Imai, Canon U.S.A., Inc. (United States)

Feng Xiao, Fairchild Imaging (United States)

2 Computational Photography

Touraj Tajbakhsh, Technische Universität Hamburg-Harburg (Germany)

3 Spectral Imaging

Manu Parmar, Stanford University (United States)

$4 \quad$ Image Processing

Ajit S. Bopardikar, Samsung Electronics, India Software Operations Ltd. (India)

5 Sensors and Optics

Peter B. Catrysse, Stanford University (United States)

$6 \quad$ Image Enhancement

Sebastiano Battiato, Università degli Studi di Catania (Italy)

$7 \quad$ Image Quality in Digital Photography: Joint Session with Conference 7867

Jon S. McElvain, Digital Imaging Systems (United States)

Peter D. Burns, Carestream Health, Inc. (United States)

$8 \quad$ High Dynamic Range Imaging: Joint Session with Conference 7867

Ricardo J. Motta, Attom Research (United States)

Susan P. Farnand, Rochester Institute of Technology (United States) 


\section{Introduction}

Welcome to the proceedings of the 7th annual Digital Photography Conference that takes place on January 24-25, 2011. The conference is part of the 2011 IS\&T/SPIE Electronic Imaging: Science and Technology Symposium, held at the Hyatt Regency Hotel, San Francisco Airport, California, United States. This proceedings volume contains the technical papers in support of the presentations at the conference.

Willard S. Boyle and George E. Smith were awarded the Nobel Prize in Physics in 2009 for the invention of the first successful imaging technology using a digital sensor, a CCD (Charge-Coupled Device) in 1969 while working at Bell Laboratories. The CCD as the digital camera's electronic eye revolutionized photography. Since the pioneering work by Boyle and Smith, digital photography has enjoyed technology advancement and incredible commercial success with new exciting developments and technological challenges in the horizon. The Digital Photography Conference brings together a compilation of the latest development in the field of digital photography by researchers and engineers working in the imaging field.

This volume starts with an invited paper that gives a summary of high dynamic range image sensor architectures by Boyd Fowler. The technical contributions comprise articles about recent progress on digital photography and all its relevant areas, from optics, sensors, processing and reproduction, including advanced applications such as spectral imaging and computational photography.

The Digital Photography Conference has successfully used a peer-review process to select papers for the proceedings. This process ensures quality of the published articles: giving constructive feedback on author's submissions for writing the final manuscript. A single-blind review process was conducted for submitted papers and each submission had at least 4 reviews with an average of 5 reviews per submission. This year we also have two joints sessions with the Conference on Image Quality and System Performance VIII on Image Quality in Digital Photography and High Dynamic Range Imaging.

Thanks to the generous support from our sponsors last year, we started offering two prizes in recognition of outstanding work selected in the proceedings. Based on the very positive feedback we received thereafter, we decided to continue offering these two prizes in this year's Digital Photography VII conference as well. Both awards will be selected by the chairs and program committee and announced during the conference: 
- Best Paper - sponsored by Fairchild Imaging

- Best Student Paper - sponsored by Canon U.S.A., Inc.

The conference activities do not stop at the end of the January meeting. The Digital Photography Conference provides a Linkedin group entitled "Digital Photography Conference (IS\&T/SPIE Electronic Imaging Symposium)" that has the objective to create a community to share ideas and post announcements relevant to digital photography. You are encouraged to join this Linkedln group. Also, if you are interested in participating in the organization of this conference, please contact any of the chairs.

The 2011 Digital Photography Conference at the Electronic Imaging Symposium continues a tradition of presenting the latest knowledge and technologies relevant to digital photography and we are going to continue exploring new endeavors in this field for future editions of this conference.

\author{
Francisco H. Imai \\ Feng Xiao \\ Jeffrey M. DiCarlo \\ Nitin Sampat \\ Sebastiano Battiato
}

